\title{
小特集「技術者教育における産学のビジョン共有」 の趣旨
}

\author{
Purpose of the Mini Special Issue on \\ "Sharing Vision of Engineering Education between Academia \& Industry" \\ 編集担当委員 佐 藤 之 彦※ \\ 濱 本 和 彦*2
}

技術者教育は，大学や高専などの高等教育機関におけ る教育からスタートし，卒業生が産業界に就職した後の 企業内教育へと続き，さらには生涯にわたる継続研鑽へ とつながっています．これらの一続きの教育の機会をよ り有効に機能させるためには，育成すべき技術者像や身 につけさせるべき知識，能力あるいは意識について，産 学がビジョンを共有した上で，それぞれにおける技術者 育成を行うことが必要です。しかし，現実には高等教育 機関が目指す技術者教育と，企業が期待している技術者 教育の間に何らかのミスマッチが存在しているという指 摘は，これまでにも数多くありました．高等教育機関と 産業界を貫く技術者教育の総合的な充実を図り，次の時 代を担う技術者を育成するためには，技術者教育の産学 それぞれの考え方を相互に理解しビジョンを共有するこ とが重要と考えられます。

以上のような視点に立って, 高等教育機関と産業界に
おける技術者教育に関するビジョンの共有に向けた先進 的な取り組み事例などに関する情報を提供し, 高等教育 機関と産業界の双方における技術者教育の発展に資する ことを目的に特集号を企画し，幅広く原稿を募集しまし た. その結果, 報告 1 件, 論説 4 件, 事例紹介 3 件から 構成される小特集を掲載することができました，その内 容は，高等教育政策に関する動き，高等教育機関におけ る産業界のニーズの取り込みに向けた調查研究, 企業に おける高等教育機関との連携，海外における技術者教育 における産学連携の現状など多岐にわたっており，今後 必要となる技術者教育における産学のビジョン共有を進 める上で参考になるものとなっています.

本小特集が, 高等教育と産業界の共通ビジョンに基づ く連続性の上に, 将来を支える有為な人材の育成を加速 するための一助となれば幸いです. 